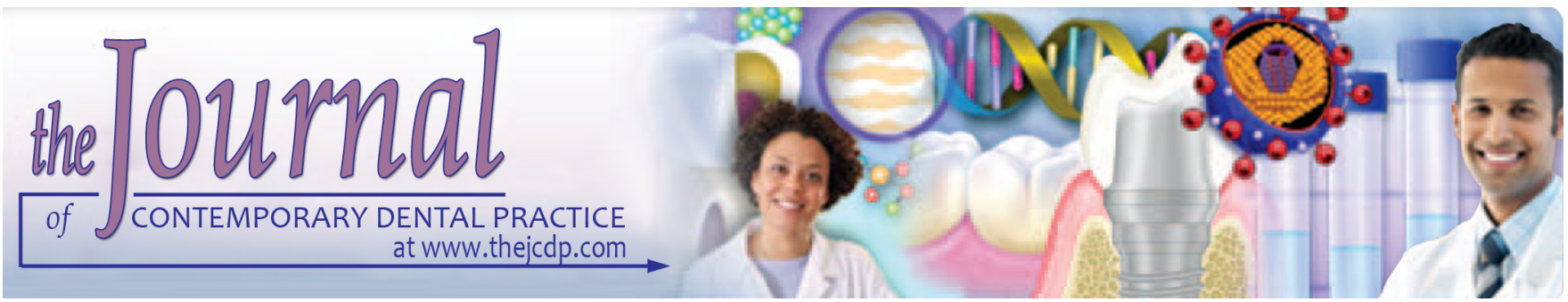

\title{
Hepatitis B Immunization Analysis: Tracking of Antibody Levels among Dental Patients
}

\author{
${ }^{1}$ Bruno Wakayama, ${ }^{2}$ Clea AS Garbin, ${ }^{3}$ Artenio JS Garbin, ${ }^{4}$ Tania A Saliba, ${ }^{5}$ Artenio JI Garbin
}

\begin{abstract}
Aim: To verify the immunization status of dental students against HBV using an immunochromatographic rapid test and explore its associated protective and preventive effects against the disease.
\end{abstract}

Material and methods: This transversal epidemiological study was conducted in a public dental school in Brazil. A total of 263 dental students who were at clinical practice were invited to participate in the study. A semi-structured questionnaire that investigated the issues related to the theme was created for data collection. An immunochromatographic test for the detection of anti-Hepatitis B surface antigen was used to verify the immunization status. Data were analyzed using the Statistical Package for the Social Sciences (SPSS).

Results: Approximately $59.2 \%$ of the participants did not know the etiological agent of hepatitis B infection, and $36.6 \%$ did not know the number of doses of hepatitis $B$ vaccines. Furthermore, $53.2 \%$ of the participants were immunized against HBV. Logistic regression showed that those who received less than three doses of the vaccine $(\mathrm{OR}=2.539)$ or did not know how many doses they received $(O R=3.022)$ had higher risks of not developing the immunity. Moreover, age $(O R=0.834)$ was a protective factor against non-immunization.

Conclusion: There was a low prevalence of dental students who were immunized against HBV. The number of vaccine doses received and the participants' age had significant associations with the immunization status.

Clinical significance: Deals with an issue of major impact on the public health because of the high rates of hepatitis $B$ in

\footnotetext{
1,2,4,5Department of Pediatric and Social Dentistry, School of Dentistry, UNESP-São Paulo State University, Araçatuba, São Paulo, Brazil

${ }^{3}$ Salesian Catholic University Center Auxilium, Araçatuba, São Paulo, Brazil

Corresponding Author: Clea AS Garbin, Department of Pediatric and Social Dentistry, School of Dentistry, UNESP_ São Paulo State University, Araçatuba, São Paulo, Brazil, Mobile: 5518 991648440, e-mail: cgarbin@foa.unesp.br, brunowakayama@gmail.com
}

the general population, as well as the lack of knowledge of the subject by a large part of dental surgeons and dental students.

Keywords: Dental students, Dentistry, Hepatitis B, Hepatitis B vaccine.

How to cite this article: Wakayama B, Garbin CAS, Garbin AJS, Saliba TA, Garbin AJI. Hepatitis B Immunization Analysis: Tracking of Antibody Levels Among Dental Patients. J Contemp Dent Pract 2019;20(1):13-19.

Source of support: Nil

Conflict of interest: None

\section{INTRODUCTION}

Hepatitis B virus (HBV) infection is considered a public health problem, for it is a pandemic disease that generates great impact on the general population, due to its high infectivity and high morbidity and mortality rates. According to the World Health Organization (WHO), approximately 240 million people are HBV carriers in the chronic state, susceptible to serious complications of cirrhosis and hepatocellular carcinoma. ${ }^{1,2}$

HBV was found to have higher rates of drug resistance, being considerably more resistant than the human immunodeficiency virus, leading to high rates of silent carriers in the chronic state. ${ }^{3}$ The highest prevalence of the disease is observed among healthcare professionals, as they are more exposed and prone to infection than the general population through direct contact with the virus or by other modes of transmission. Among the healthcare professionals, odontologists are at higher risk of HBV infection due to their intimate contact with blood and saliva, as well as due to imminent accidents with contaminated sharps. ${ }^{4}$

In this context, the primary methods to reduce the risks of HBV infection must be explored in dental schools to promote the use of personal protective equipment and establish the importance of adhering to the post-exposure prophylaxis following a needlestick or sharps injury. ${ }^{5}$ In addition, the adoption of biosecurity measures in 
the treatment of patients is indispensable in the clinical conduct, as it is the best method to prevent the direct transmission of pathogenic microorganisms and crossinfections inside the dental clinic. ${ }^{6}$

The primary method of preventing hepatitis $B$ infection is through vaccination against HBV; therefore, it is considered a valuable method to maintain the health integrity of healthcare professionals and patients, hence reducing the spread and incidence of the disease. This protective measure, besides being the safest form of defense against the virus, is highly efficient due to its easy access and large population coverage. ${ }^{7}$ Vaccination against HBV has been recommended to healthcare workers since the early 1990s and is currently distributed free of charge in all public health offices of unified health system (SUS), a public healthcare system in Brazil. This protective action is intended for the most vulnerable groups and age ranges previously determined by the Ministry of Health. ${ }^{8}$

Immunization against $\mathrm{HBV}$, even after the complete vaccination series, does not occur in $5 \%$ of all vaccinated individuals. The primary method of verifying one's immunity is through anti-HBs seroconversion test, which is recommended to all healthcare professionals, due to their occupational activities. ${ }^{8,9}$ This test is indispensable after the three-dose schedule to confirm an individual's immune status through detection of anti-HBsAg antibody titer in the serum. ${ }^{10}$

Verification of immunization status against HBV is still an uncommon practice among dental professionals, especially among academic professionals, for this conduct is not representative in the literature. Thus, discussions over this self-care practice are necessary.

The present study aimed to verify the immunization status of dental students against HBV using a rapid immunochromatographic test for the detection of antiHBsAg antibodies. Additionally, the associations between immunization and protective and preventive practices against the disease were explored.

\section{MATERIALS AND METHODS}

\section{Study Design}

In this epidemiological study, transversal cut and quantitative analysis were conducted in a public dental school in Brazil. The study population was all undergraduate students, who developed clinical activities ( $n=263$ ). The sample consisted of 235 academics who accepted to participate in the research. We excluded those who were taking only theoretical subjects, who were absent on the day of data collection, and who refused to undergo an anti-HBsAg test.

\section{Data Collection}

Data collection was divided into two phases. The first phase involved the administration of semi-structured and self-administered questionnaires to the participants of the study. The questionnaire contained a series of questions regarding the aspects of prevention, protection, self-care, vaccination, and immunization against hepatitis B. ${ }^{11,12}$ Firstly, a pilot experiment was conducted, with the sample not included in the study, to check for possible corrections and adjustments in the research tool. The questionnaires were administered during break times. After filling them out, the students who declared having been vaccinated were guided to an auxiliary room to carry out the next phase of the study.

In the second phase, to verify their immunization status, an anti-HBsAgtest was performed. It is an immunochromatographic test that detects the presence of anti-HBsAg antibodies in whole blood, serum, or human plasma samples based on the sandwich principle. The device shows two regions, the test region (T) and the control region (C), which, by the appearance of two colored bands in the respective regions, indicate a positive result, i.e., an immunized individual.

This happens because anti-HBsAg antibodies (from blood samples), after binding to the HBsAg colloidal gold (antigen-antibody mixture), bind to the HBsAg present in region $\mathrm{T}$, forming a pinkish-red band. Next, the mixture migrates to region $\mathrm{C}$ and the conjugated colloidal gold that is not bound to the component in the test region joins the anti-HBsAg present in the control area, which forms a pinkish-red band and confirms one's immunization status.

With regard to blood specimen collection, the participants were submitted for a fingerstick procedure, and $100 \mu \mathrm{L}$ of blood was collected, which was immediately pipetted into the device's indicated place. The result was confidentially read 15-20 minutes after the beginning of the test. The presence of two-colored bands at regions $\mathrm{T}$ and $\mathrm{C}$ indicated a positive result (immunized), while the presence of one colored band at region $C$ indicated a negative result (not immunized).

Two researchers who were previously trained for conducting the anti-HBsAg rapid tests by fingerstick conducted the study. The test was performed following all biosecurity standards for the protection of the participants and in accordance with the manufacturer's recommendations to guarantee the reliability of the results.

\section{Statistical Analysis}

For the analysis of data, descriptive statistics were used to characterize the individuals and variables of the study by 
measures of central tendency and dispersion. In bivariate analysis, to verify the existing variations among the dependent and independent variables, Pearson's Chisquare test, Fisher's exact test, and maximum likelihood estimation were employed, with a $p$ value of $<0.050$. The multivariate analysis, by binomial logistic regression, was elected to adjust the control of multiple confounding variables and identify the effect modification factors from the binary event. All bivariate analysis associations with a $p$ value of $<0.200$ were included in this model. The results were expressed as odds ratio (OR) and confidence interval was adjusted at 95\%. All statistical data analyses were performed using SPSS version 21.0.

\section{Ethical Considerations}

The present study was carried out according to the guidelines laid down in the Declaration of Helsinki and approved by the research ethics committee in Brazil under protocol number 1.552.870. Informed consent was obtained from all participants included in the study.

\section{RESULTS}

A total of 263 dental students who were at clinical practice were invited to participate in the study. Among these, $235(89.35 \%)$ were included in the study after agreeing to participate in the second phase of the survey, with the application of the rapid immunochromatographic test for the detection of anti-HBsAg (Table 1).

Approximately 93.2\% confirmed that they had a previous orientation about hepatitis B issues, the dental school being the major source of information about the

Table 1: Characterizing dental students' profiles

\begin{tabular}{lll}
\hline Profile & $n$ & $\%$ \\
\hline Sex & & \\
Female & 168 & 71.4 \\
Male & 67 & 28.6 \\
\hline Age group & & \\
19 & 6 & 2.5 \\
20 to 24 & 182 & 77.4 \\
25 to 29 & 21 & 8.9 \\
30 ormore & 3 & 1.3 \\
No answer/ ignored & 23 & 9.8 \\
\hline Color & & \\
White & 199 & 84.7 \\
Black & 4 & 1.7 \\
Brown & 20 & 8.5 \\
Yellow & 12 & 5.1 \\
\hline How long at clinical practice? & & \\
Lessthan a year & 32 & 13.6 \\
Between1and 2 years & 86 & 36.6 \\
3yearsor more & 113 & 48.1 \\
No answer/ ignored & 4 & 1.7 \\
\hline Total & 235 & 100 \\
\hline
\end{tabular}

theme. However, when asked about the etiological agent of the disease and the appropriate dose of hepatitis vaccine, $59.2 \%$, and $36.6 \%$, respectively, did not know or provided an answered (Table 2).

About prevention and protection, $48.5 \%$ of the participants declared having received three doses of vaccine against hepatitis $B$, among which only $23 \%$ received the immunization confirmation test and only half of them were immunized. Approximately 20.9\% of the participants had a history of sharps injuries. With regard to the results of the anti-HBsAg tests conducted in the second phase of the study, $46.8 \%$ of the participants yielded negative test results, confirming the nonimmunization against HBsAg antigen (Table 3).

In Table 4, using bivariate analysis, the statistical associations between immunization and the variable "How many doses of the vaccine did you take?" were evidenced ( $p=0.010)$.

Using multivariate analysis, it was observed that those who received less than three doses $(\mathrm{OR}=2.539)$ had a higher risk of not developing the immunity; those who could not tell the number of doses they received showed an even greater risk $(\mathrm{OR}=3.022)$ (Table 5). Moreover, age $(\mathrm{OR}=0.834)$ proved to be a protective factor against non-immunization.

Table 2: Absolute and percentual distribution of dental students' knowledge about hepatitis B

\begin{tabular}{|c|c|c|}
\hline Knowledge & $n$ & $\%$ \\
\hline \multicolumn{3}{|c|}{$\begin{array}{l}\text { Have you ever had any orientation about } \\
\text { hepatitis B? }\end{array}$} \\
\hline Yes & 219 & 93.2 \\
\hline No & 16 & 6.8 \\
\hline \multicolumn{3}{|c|}{ If yes, where did you get it? } \\
\hline Dental school & 203 & 92.7 \\
\hline Others & 16 & 7.3 \\
\hline \multicolumn{3}{|c|}{$\begin{array}{l}\text { Do you know the etiological agent of } \\
\text { hepatitis B? }\end{array}$} \\
\hline Yes & 95 & 40.4 \\
\hline No & 139 & 59.2 \\
\hline No answer/ ignored & 1 & 0.4 \\
\hline \multicolumn{3}{|c|}{ You think the risk of contracting hepatitis $B$ is: } \\
\hline Very high & 185 & 78.8 \\
\hline Medium & 38 & 16.2 \\
\hline Low & 6 & 2.5 \\
\hline No answer/ignored & 6 & 2.5 \\
\hline \multicolumn{3}{|c|}{ You think the risk for dental assistants is: } \\
\hline High & 165 & 70.2 \\
\hline Medium & 53 & 22.6 \\
\hline Low & 12 & 5.1 \\
\hline No answer/ignored & 5 & 2.1 \\
\hline \multicolumn{3}{|c|}{$\begin{array}{l}\text { How many doses are there in the vaccine } \\
\text { series against hepatitis } B \text { ? }\end{array}$} \\
\hline Correctanswer & 149 & 63.4 \\
\hline Incorretanswer & 84 & 35.7 \\
\hline No answer/ignored & 2 & 0.9 \\
\hline
\end{tabular}


Table 3: Absolute and percentual distribution of prevention and protection against hepatitis $\mathrm{B}$.

\begin{tabular}{|c|c|c|}
\hline Prevention and Protection & $n$ & $\%$ \\
\hline \multicolumn{3}{|c|}{ Have you had or do you have hepatitis B? } \\
\hline Less than 3 doses & 67 & 28.5 \\
\hline 3 doses & 114 & 48.5 \\
\hline No answer/ ignored & 54 & 23.0 \\
\hline \multicolumn{3}{|c|}{$\begin{array}{l}\text { At the time, did you take the test/exam to } \\
\text { certify your immunization? }\end{array}$} \\
\hline Yes & 54 & 23.0 \\
\hline No & 162 & 68.9 \\
\hline No answer/ignored & 19 & 8.1 \\
\hline \multicolumn{3}{|l|}{ The exam result was: } \\
\hline Positive & 27 & 50.0 \\
\hline Negative & 21 & 38.9 \\
\hline I don't know & 6 & 11.1 \\
\hline \multicolumn{3}{|c|}{$\begin{array}{l}\text { Have you taken this research's } \\
\text { Anti-HBsAg test? }\end{array}$} \\
\hline Yes & 235 & 89.4 \\
\hline No & - & - \\
\hline \multicolumn{3}{|c|}{$\begin{array}{l}\text { What was the result of the immunization } \\
\text { test? }\end{array}$} \\
\hline Positive & 125 & 53.2 \\
\hline Negative & 110 & 46.8 \\
\hline
\end{tabular}

\section{DISCUSSION}

The knowledge about the forms of prevention and protection against HBV is the primary method for reducing the spread and transmission of this disease. In the present study, $93.2 \%$ of the students had known about the hepatitis B issue, and $78.8 \%$ knew the high risk of being infected by the virus. Similar data found in the international context reiterated the importance of discussing hepatitis B in the academic context for safer and more conscious odontological practice. . $^{13-15}$

Regarding the preventive practices against HBV, the washing and sanitizing of hands after each clinical procedure $(81.0 \%)$ as well as following biosecurity protocols were the main protective measures mentioned. The research results differ from those of the present study, which reported that $43 \%$ and $47.9 \%$ of the students, respectively, washed their hands between glove changes. ${ }^{16,17}$ In the healthcare field, a hand washing routine is an important part of self-care maintenance, as the hands are the main media for pathogen accumulation and transmission. ${ }^{18}$ Moreover, maintaining proper hygiene and the use of personal protective equipment are considered as the primary measures to reduce the occurrence of infection after mucocutaneous exposure. ${ }^{19}$

Approximately $89.7 \%$ of the academic professionals confirmed that they received the hepatitis B vaccine, of which only $48.5 \%$ completed the three doses of the vaccine. This negligence toward the vaccination protocol was similar to that reported in other countries such as Yemen $(50 \%),{ }^{16}$ Saudi Arabia $(41 \%),{ }_{1}^{13}$ India $(44.4 \%),{ }^{14}$ and Brazil
Table 4: Bivariate analysis among immunization, knowledge, and prevention and protection practices against hepatitis $\mathrm{B}$.

\begin{tabular}{|c|c|c|c|c|c|}
\hline \multirow[b]{3}{*}{ Independent variables } & \multicolumn{4}{|c|}{$\begin{array}{l}\text { Result of the } \\
\text { immunization test: }\end{array}$} & \multirow[b]{3}{*}{$p$-value } \\
\hline & \multicolumn{2}{|c|}{ Positive } & \multicolumn{2}{|c|}{ Negative } & \\
\hline & $n$ & $\%$ & $n$ & $\%$ & \\
\hline \multicolumn{5}{|c|}{$\begin{array}{l}\text { Have you had any orientation } \\
\text { about hepatitis B? }\end{array}$} & \multirow{3}{*}{$0.433^{*}$} \\
\hline Yes & 118 & 94.4 & 101 & $9 ., 8$ & \\
\hline No & 7 & 5.6 & 9 & 8.2 & \\
\hline \multicolumn{6}{|c|}{$\begin{array}{l}\text { You think the risk of } \\
\text { contracting hepatitis B is: }\end{array}$} \\
\hline High & 98 & 79.0 & 87 & 82.9 & \multirow{3}{*}{$0.702^{* * *}$} \\
\hline Medium & 22 & 17.7 & 16 & 15.2 & \\
\hline Low & 4 & 3.2 & 2 & 1.9 & \\
\hline \multicolumn{5}{|c|}{$\begin{array}{l}\text { Do you know the needlestick } \\
\text { and sharps injury protocol? }\end{array}$} & \multirow{3}{*}{$0.516^{*}$} \\
\hline Yes & 101 & 86.3 & 91 & 89.2 & \\
\hline No & 16 & 13.7 & 11 & 10.8 & \\
\hline \multicolumn{5}{|c|}{$\begin{array}{l}\text { Have you treated patients } \\
\text { infected with hepatitis B? }\end{array}$} & \multirow{3}{*}{$0.819^{*}$} \\
\hline Yes & 16 & 12.8 & 13 & 11.8 & \\
\hline No & 109 & 87.2 & 97 & 88.2 & \\
\hline \multicolumn{5}{|c|}{$\begin{array}{l}\text { Has anybody had or does } \\
\text { anybody have hepatitis B in } \\
\text { your family? }\end{array}$} & \multirow[t]{3}{*}{$1.000^{* *}$} \\
\hline Yes & 5 & 4.0 & 5 & 4.6 & \\
\hline No & 119 & 96.0 & 103 & 95.4 & \\
\hline \multicolumn{5}{|c|}{$\begin{array}{l}\text { Have you taken the vaccine } \\
\text { against hepatitis B? }\end{array}$} & \multirow{3}{*}{$0.293^{*}$} \\
\hline Yes & 118 & 94.4 & 99 & 90.8 & \\
\hline No & 7 & 5.6 & 10 & 9.2 & \\
\hline
\end{tabular}

How many doses of the

vaccine against hepatitis $B$

did you take?

$\begin{array}{llllll}\text { Less than 3 doses } & 31 & 24.8 & 36 & 32.7 & 0.010^{*} \\ 3 \text { doses } & 72 & 57.6 & 42 & 38.2 & \\ \text { I don't know } & 22 & 17.6 & 32 & 29.1 & \end{array}$

Does the hepatitis $\mathrm{B}$ vaccine

provide immunization for a

lifetime?

$0.189^{*}$

$\begin{array}{lllll}\text { Yes } & 26 & 23.2 & 23 & 23.5\end{array}$

No

$\begin{array}{llll}86 & 76.8 & 75 & 76.5\end{array}$

Have you ever had any

needlestick or sharps

injury?

$\begin{array}{lllll}\text { Yes } & 23 & 19.3 & 28 & 27.5\end{array}$

$\begin{array}{lllll}\text { No } & 96 & 80.7 & 74 & 72.5\end{array}$

* Pearson's Chi-square test

${ }^{* *}$ Fisher's exact test

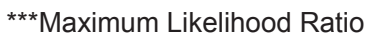

$(48.9 \%) .{ }^{20}$ However, the incidence was lower in Nepal, wherein $80.2 \%$ of dental students received a complete dose of the HBV vaccine. ${ }^{21}$ Discussions over this issue should still be emphasized due to the lack of knowledge on the number of doses of $\mathrm{HBV}$ vaccine, which can lead to incomplete vaccination and increase the risk of $\mathrm{HBV}$ infection. ${ }^{10,22}$

Vaccination against HBV is the most efficient and secure method of preventing the disease and, even though it is widespread worldwide and recommended 
Table 5: Multivariate analysis of associations found between immunization and protection and prevention practices against HBV

\begin{tabular}{|c|c|c|c|c|}
\hline \multirow[b]{2}{*}{ Variables } & \multicolumn{4}{|c|}{ Multivariate analysis } \\
\hline & $\begin{array}{l}\text { Unadjusted } \\
\text { OR } \\
\text { (CI 95\%) }\end{array}$ & \multicolumn{2}{|c|}{$\begin{array}{l}\text { Adjusted OR } \\
\text { p-value (Cl 95\%) }\end{array}$} & $p$ value \\
\hline \multicolumn{5}{|c|}{ How many doses of the vaccine against hepatitis $B$ did you take? } \\
\hline 3 doses & 1.000 & & 1.000 & \\
\hline $\begin{array}{l}\text { Less than } \\
3 \text { doses }\end{array}$ & $\begin{array}{l}1.991 \\
(1.079-3.674)\end{array}$ & 0.028 & $\begin{array}{l}2.539 \\
(1.002-6.438)\end{array}$ & 0.049 \\
\hline I don't know & $\begin{array}{l}2.494 \\
(1.285-4.839)\end{array}$ & 0.007 & $\begin{array}{l}3.022 \\
(1.105-8.259)\end{array}$ & 0.031 \\
\hline \multicolumn{5}{|c|}{ Does the hepatitis $B$ vaccine provide immunization for a lifetime? } \\
\hline Yes & 1.000 & & 1.000 & \\
\hline No & $\begin{array}{l}0.986 \\
(0.519-1.871) \\
\end{array}$ & 0.965 & $\begin{array}{l}0.853 \\
(0.399-1.826)\end{array}$ & 0.683 \\
\hline \multicolumn{5}{|c|}{ Have you ever had any needlestick or sharps injury? } \\
\hline Yes & $\begin{array}{l}1.579 \\
(0.842-2.964)\end{array}$ & 0.155 & $\begin{array}{l}1.612 \\
(0.764-3.399)\end{array}$ & 0.210 \\
\hline No & 1.000 & & 1.000 & \\
\hline Age & $\begin{array}{l}0.891 \\
(0.781-1.015)\end{array}$ & 0.083 & $\begin{array}{l}0.834 \\
(0.702-0.991)\end{array}$ & 0.040 \\
\hline
\end{tabular}

OR: odds ratio

mainly among healthcare professionals, it is underused due to incomplete vaccination scheme. ${ }^{9}$ In Brazil, initiatives for promotion of health and control of the spread of HBV were started in the 1990s, such as free vaccination to the most vulnerable groups, including the dental surgeons. From that point, public policies and guidelines directed toward the prevention of this disease were created to reduce the incidence as well as the morbidity and mortality rates. ${ }^{7}$ Nonetheless, dental students must be oriented to the importance of vaccination and must be encouraged to follow the vaccination protocol by receiving three complete doses of vaccine, as vaccination is an important aspect of self-care and responsible professional practice. ${ }^{23}$

Immunization against $\mathrm{HBV}$ is acquired after receiving three doses of HBV vaccine, although not all vaccinated individuals develop immunity. Therefore, the importance of immunological verification of anti-HBsAg antibody levels should be emphasized; in case of sharps injury and the need to follow the accident protocol, those nonimmunized individuals should immediately receive hepatitis B immunoglobulin. ${ }^{24}$

In the present study, immunization tracking was performed with an anti-HBsAg rapid test to assess the dental students' antibody serological profile. It was found that $53.2 \%$ of all academic were immunized. However, this finding differed from those reported by Sacchetto et al., ${ }^{25}$ who found the prevalence rate of $79.2 \%$ of immune individuals. Similar data were reported in Europe, where $72.98 \%$ of the individuals were immunized, ${ }^{26}$ and in Asia, where $93 \%,{ }^{27} 88.5 \%,{ }^{28}$ and $78.2 \%{ }^{11}$ of dental students showed an anti-HBsAg level of more than 100
International units per liter (IU/L). Nonetheless, studies conducted in Brazil and Italy demonstrated lower levels of anti-Hbs antibodies among research participants, accounting for $16.4 \%$ and $54 \%$ of immunized individuals respectively. ${ }^{29,30}$

With regard to the results of the study, immunization rates of students who underwent the immunochromatographic test $(53.2 \%)$ were based on their answers; when they were asked if they had taken the anti-HBs test after the vaccination scheme and were asked about the results, 50\% confirmed that they developed immunity. Besides, the low prevalence of individuals who received three doses of the vaccine $(48.5 \%)$ corroborates to the insufficient production of anti-HBs antibodies, determining a low expectation for immunization. This similarity in the results confirms that the immunization rate among academic professionals remained low. Hence, substantial efforts must be made to emphasize the importance of vaccination as part of self-care maintenance. Therefore, classroom discussions about the theme as well as reformulation in the approach of the issue in the universities must be carried out to reduce negligence toward the vaccination protocol and guarantee immunity.

The present study showed that there exists an association between the number of doses of the vaccine taken and immunization, highlighting the fact that those who received less than three doses of the vaccine $(\mathrm{OR}=2.539)$ or could not answer $(\mathrm{OR}=3.022)$ have a higher risk of not developing immunity. Batista et al., ${ }^{31}$ and Sernia et al., ${ }^{30}$ verified that the rates of HBV vaccine seropositivity werehigher among dental surgeons $(p=0.04)$ and dental students $(p=0.0001)$, respectively, who received three doses of vaccine than in those who only received two doses or less. Likewise, Mahboobi et al., ${ }^{32}$ reiterated this hypothesis in their study when they reaffirmed the existing association between the variables, vaccine doses, and immunization.

The age variable in this study was verified as a protective factor against non-immunization. After each year, non-immunized individuals showed an estimated risk reduction of $16.6 \%$. This finding is related to the vaccine's efficacy and immunogenicity, which brings immunization up to $90 \%$ in healthy young adults. ${ }^{33}$

The methodology employed in this study, with the use of immunochromatographic rapid test, is the most recommended method for detecting anti-HBs antibodies in population studies due to its accessible cost, technical ease at performance, lower discomfort, and higher adherence of participants, and because it does not require the use of great infrastructure or technological apparatus. Moreover, it becomes attractive for immunological 
tracking in professionals who experience occupational accidents, in cases where there are no available resources for immunoenzymatic and electrochemiluminescence laboratorial analysis. ${ }^{34-36}$

Regarding the limitations of the study, because it is a cross-sectional study, it is not possible to infer the causality between the outcomes found. Furthermore, by using a self-administered instrument, memory recall may be an influencing confounding factor, especially in the issues of recognized positive desirable. ${ }^{37}$ Regarding the use of immunochromatographic technology, this method has limitations on sensitivity aspects, and confirmation with other tests is recommended in certain situations. However, it is emphasized that the use of immunochromatographic technology is recommended in screening and population studies, and it is necessary to interpret the results associated with the clinical and epidemiological peculiarities of each specific case. ${ }^{38}$

\section{CLINICAL SIGNIFICANCE}

Deals with an issue of major impact on the public health because of the high rates of hepatitis B in the general population, as well as the lack of knowledge of the subject by a large part of dental surgeons and dental students.

\section{CONCLUSION}

This study verified with the use of the immuno-chromatographic rapid test that dental students showed a low production of anti-HBsAg antibodies; thus, only a few dental students were immunized against HBV. The number of doses of vaccine taken had a statistical association with the immunization status. In addition, evidence indicated that the students' age was a protective factor against non-immunization.

\section{REFERENCES}

1. World Health Organization. Guidelines for the prevention, care and treatment of persons with chronic hepatitis B infection. Geneva: WHO;2015.

2. Puga MAM, Bandeira LM, Weis SMS, Fernandes FRP, Castro LS, Tanaka TSO,et al. High-risk behaviors for hepatitis B and C infections among female sex workers. Rev Soc Bras Med Trop 2018;51(2):198-202.

3. Nouetchognou JS, Ateudjieu J, Jemea B, Mbanya D. Accidental exposures to blood and body fluids among health care workers in a Referral Hospital of Cameroon.BMC Res Notes 2016;9:94.

4. Brailo V, Pelivan I,Škaricić J,Vuletić M, Dulcić N, Cerjan-Letica G. Treating patients with HIV and Hepatitis B and C infections: Croatian dental students' knowledge, attitudes, and risk perceptions. J Dent Educ 2011;75(8):1115-1126.

5. Adenlewo OJ, Adeosun PO, Fatusi OA. Medical and dental students' attitude and practice of prevention strategies against hepatitis B virus infection in a Nigerian university. Pan Afr Med J 2017;28:33.
6. Pimentel MJ, Batista Filho MM, Santos JP, Rosa MR. Biosecurity: behavior of dental students in control of cross infection. Cadernos Saúde Coletiva. 2012;20(4):525-532.

7. Garbin AJI, Wakayama B, Garbin CAS. Negligência no autocuidado em saúde: a imunização contra a hepatite B na Odontologia. Arch Health Invest 2016;5(2):85-89.

8. Ministério da Saúde (MS). Protocolo clínico e diretrizes terapêuticas para prevenção da transmissão vertical de HIV, sífilis e hepatites virais.Brasília: MS;2015.

9. Qin YL, Li B, Zhou YS, Zhang X, Li L, Song B, et al. Prevalence and associated knowledge of hepatitis B infection among healthcare workers in Freetown, Sierra Leone. BMC Infect Dis 2018;18(1):315.

10. Alavian SM, Izadi M, Zare AA, Lankarani MM, Assari S, Vardi MM. Survey of the level of anti-HBs antibody titer in vaccinated Iranian general dentists. Special Care in Dentistry. 2008 Nov;28(6):265-270.

11. Lasemi E, Haddadpour N, Navi F, Rakhshan A, Rakhshan V. Rate of acquired immunity in dental students after hepatitis B vaccination. Dent Res J 2011;8(3):128-131.

12. Ministério da Saúde (MS). Estudo de prevalência de base populacional das infecções pelos vírus das hepatites A, B e C nas capitais do Brasil. Brasília: MS;2010.

13. Al-Shamiri HM, AlShalawi FE, AlJumah TM, AlHarthi MM, AlAli EM, AlHarthi HM. Knowledge, Attitude and practice of hepatitis B virus infection among dental students and interns in Saudi Arabia. J ClinExp Dent 2018;10(1):e54-60.

14. Kumar S, Basak D, Kumar A, Dasar P, Mishra P, Kumar A, et al. Occupational hepatitis B exposure: a peek into indian dental students' knowledge, opinion, and preventive practices. Interdiscip Perspect Infect Dis 2015;2015:190174.

15. Li X, Kang H, Wang S, Deng Z, Yang T, Jia Y, et al. Knowledge, attitude, and behavior of hepatitis $\mathrm{B}$ virus infection among chinese dental interns. Hepat Mon 2015;15(5):e25079.

16. Halboub ES, Al-Maweri SA, Al-Jamaei AA, Tarakji B, AlSoneidar WA. Knowledge, attitudes, and practice of infection control among dental students at Sana'a University, Yemen. J Int Oral Health 2015;7(5):15-19.

17. Rahman B, Abraham S, Alsalami AM, Alkhaja FE, Najem SI. Attitudes and practices of infection control among senior dental students at college of dentistry, university of Sharjah in the United Arab Emirates. Eur J Dent 2013;7(suppl 1):S15-9.

18. Lingawi H, Maher Y, Afifi I. Impact of Educational Intervention for Hand Hygiene on Dental Students' Knowledge, Attitude, and Bacterial Contamination Level on Hands. J Contemp Dent Pract 2017;18(12):1164-1172.

19. Mahesh R, Arthi C, Victor S, Ashokkumar S. Hepatitis B infection awareness among dental graduate students: a cross sectional study. IntSch Res Notices2014;2014:389274.

20. Souza EP, Teixeira MS. Hepatitis B vaccination coverage and postvaccination serologic testing among medical students at a public university in Brazil. Rev Inst Med Trop São Paulo. 2014;56(4):307-311.

21. Bhattarai S, Smriti KC, Pradhan PMS, Lama S, Rijal S. Hepatitis $B$ vaccination status and Needle-stick and Sharps-related Injuries among medical school students in Nepal: a cross-sectional study. BMC Res Notes 2014;7:774.

22. Martins RJ, Garbin CAS, Garbin AJI, Prieto AC. Conhecimento e atitudes de profissionais da saúde frente à exposição ocupacional a material biológico. Cienc Trabaj 2011;13(40):113-115.

23. Pathoumthong K, Khampanisong P, Quet F, Latthaphasavang V, Souvong V, Buisson Y. Vaccination status, knowledge and 
awareness towards hepatitis B among students of health professions in Vientiane, Lao PDR. Vaccine 2014;32(39):4993-4999.

24. Garcia LP, Facchini LA. Hepatitis B vaccination among primary health care workers. Cad SaúdePública 2008;24(5):1130-1140.

25. Sacchetto MSLS, Barros SSLV, Araripe TA, Silva AM, Faustino SKM, Silva JMN. Hepatitis B: knowledge, vaccine situation and seroconversion of dentistry students of a Public University. Hepat Mon 2013;13(10):e13670.

26. Arias-Moliz MT, Rojas L,Liébana-Cabanillas F, Bernal C, Castillo F, Rodríguez-Archilla A, et al. Serologic control against hepatitis B virus among dental students of the University of Granada, Spain. Med Oral Patol Oral Cir Bucal 2015;20(5):e566-e571.

27. Abdolsamadi HR, Vaziri PB, Abdollahzadeh SH, Kashani $\mathrm{KM}$, Vahedi MO. Immune response to hepatitis B vaccine among dental students. Iranian Journal of Public Health. 2009;38(2):113-118.

28. Momeni N, Akhoundi MS, Alavian SM, Shamshiri AR, Norouzi M, Mahboobi N, Moosavi N, Jazayeri SM. HBV Vaccination status and response to hepatitis $b$ vaccine among iranian dentists, correlation with risk factors and preventive measures. Hepatitis monthly. 2015 Jan;15(1)e20014.

29. Martins AMEBL, Costa FM, Ferreira RC, Santos NPE, Magalhaes TA, Sá MAB et al. Factors associated with immunization against Hepatitis B among workers of the Family Health Strategy Program. Rev Bras Enferm 2015;68(1):84-92.

30. Sernia S, Ortis M, Antoniozzi T, Maffongelli E, La Torre G. Levels of Anti-HBs antibody in HBV-vaccinated students enrolled in the Faculty of Medicine, Dentistry and Health Professions of a Large Italian University. BioMed Res Int 2015;2015:712020.
31. Batista SM, Andreasi MS, Borges AM, Lindenberg ASC, Silva AL, Fernandes TD, et al. Seropositivity for hepatitis B virus, vaccination coverage, and vaccine response in dentists from Campo Grande, MatoGrosso do Sul, Brazil. MemInst Oswaldo Cruz 2006;101(3):263-267.

32. Mahboobi N, Agha-Hosseini F, Mahboob N, Safari S, Lavanchy D, Alavian SM. Hepatitis B virus infection in dentistry: a forgotten topic. J Viral Hepat 2010;17(5):307-316.

33. Moraes JC, Luna EJ, Grimaldi RA. Immunogenicity of the Brazilian hepatitis B vaccine in adults.Rev SaúdePública 2010;44(2):353-359.

34. Bottero J, Boyd A, Gozlan J, Lemoine M, Carrat F, Collignon A, et al.Performance of rapid tests for detection of HBsAg and anti-HBsAb in a large cohort, France. J Hepatol2013;58(3):473478.

35. Sato K, Ichiyama S, Iinuma Y, Nada T, Shimokata K, Nakashima NE. Evaluation ofimmunochromatographic assaysystems for rapid detection of hepatitis B surface antigen and antibody, DainascreenHBsAg and DainascreenAusab. J ClinMicrobiol1996;34(6):1420-1422.

36. Chevaliez S, Challine D, Naija H, Luu TC, Laperche S, Nadala $\mathrm{L}$, et al.Performance of a new rapid test for the detection of hepatitis B surface antigen in various patient populations. J ClinVirol 2014;59(2):89-93.

37. Assunção AA, Araújo TM, Ribeiro RBN, Oliveira SVS. Hepatitis $B$ vaccination and occupation exposure in the healthcare sector in Belo Horizonte, Southeastern Brazil. Rev SaúdePública 2012; 46(4):665-673.

38. Barbosa JR, Colares JKB, Flores GL, Cortes VF, Miguel JC, Portilho $\mathrm{MM}$ et al. Performance of rapid diagnostic tests for detection of Hepatitis B and C markers in HIV infected patients. Journal of Virological Methods 2017; 248:244-249. 